\title{
Air and Moisture Tolerant Synthesis of a Chelated bis(NHC) Methylpalladium(II) Complex Relevant to Alkyl Migration Processes in Catalysis
}

\author{
Michael G. Gardiner, ${ }^{a}$ Curtis C. Ho, ${ }^{* a}$ David S. McGuinness, ${ }^{a}$ and Yi Ling Liu ${ }^{\mathrm{a}}$ \\ aSchool of Natural Sciences - Chemistry, Private Bag 75, University of Tasmania, Hobart, \\ Tasmania, 7001, Australia. Fax: +61 3 62262858; Tel: +61 362262404 \\ *Corresponding Author e-mail: Curtis.Ho@utas.edu.au
}

\begin{abstract}
An air- and moisture-tolerant alternate synthetic pathway to the preparation of a cationic chelated bis(NHC) methylpalladium(II) complex, [ $\left.\left\{(\mathrm{MesIm})_{2} \mathrm{CH}_{2}\right\} \mathrm{Pd}(\mathrm{Me})(\mathrm{NCMe})\right]\left[\mathrm{PF}_{6}\right]$, is described. The pathway involves the isolation of a bis(NHC) $\operatorname{Ag}(\mathrm{I})$ complex, $\left[\left\{(\mathrm{MesIm})_{2} \mathrm{CH}_{2}\right\}_{2} \mathrm{Ag}_{2}\right]\left[\mathrm{PF}_{6}\right]_{2}$, via metallation of the corresponding diimidazolium salt with $\mathrm{Ag}_{2} \mathrm{O}$ followed by carbene transfer to [(COD)PdBrMe]. This new method avoids a previously reported unstable intermediate that displayed rapid decomposition at room temperature, attaining the targeted cationic methylpalladium(II) complex in high yield. CO/ethylene copolymerisation catalysis trials are reported showing solvent dependent catalyst lifetime and copolymer yields. Preliminary ethylene insertion studies are also outlined revealing possible pathways leading towards catalyst deactivation.
\end{abstract}

\section{Introduction}

Transition metal-alkyl/aryl complexes serve as an important class of catalysts for homogeneous alkene oligomerisation/polymerisation reactions. ${ }^{1,2,3}$ It has also been established that the generation of a vacant coordination site adjacent the alkyl/aryl group allows for rapid migration processes leading to significantly more active catalyst species when compared to their coordinatively saturated analogues. ${ }^{4}$

Group 10-based catalysts are especially relevant due to their functional group tolerance enabling copolymerisation of polar monomers where traditional Ziegler-Natta type catalysts are incompatible. ${ }^{5}$ The formation and catalytic utility of palladium(II) alkyl complexes featuring various supporting ligands such as monodentate NHCs, ${ }^{6}$ chelated diimine, ${ }^{7}$ bisphosphine ${ }^{8}$ and even hybrid $\mathrm{P} / \mathrm{O},{ }^{9} \mathrm{P} / \mathrm{N},{ }^{10}$ and $\mathrm{NHC} / \mathrm{O}^{11}$ mixed donor ligands are well documented all displaying varying degrees of catalytic competence.

Interestingly, initial studies investigating alkyl migration processes performed with monodentate NHC methylpalladium(II) complexes only resulted in limited catalytic utility due to high susceptibility of $\mathrm{CO}, \mathrm{Me}$ and/or $\mathrm{H}$ insertion into the $\mathrm{Pd}-\mathrm{C}$ (NHC) bond leading to catalyst deactivation resulting from the formation of 2acyl/alkylimidazolium salts via reductive elimination. ${ }^{6}$ It was not until Herrmann et al. ${ }^{12}$ demonstrated the viability of dicationic chelated bis(NHC) palladium(II) complexes in $\mathrm{CO} /$ ethylene copolymerisation did the potential advantages of chelated bis(NHC) ligands in this class of catalysis become evident. The advantage of chelated bis(NHC) ligands was also observed by Green et al. noting that thermal decomposition of related $\mathrm{Ni}(\mathrm{II})$ complexes did not proceed via reductive elimination. ${ }^{13}$ However, despite extensive reports dedicated to the preparation and catalytic applications of chelated bis(NHC) palladium(II) complexes, methods for the generation of their metal-alkyl derivatives remain limited to strategies that necessitate the formation of highly air, moisture and temperature sensitive free carbene intermediates. ${ }^{14}$ The first report for the preparation of a cationic chelated bis(NHC) methylpalladium(II) complex was by Slaughter and co-workers employing the free carbene strategy which involved the isolation of an unstable intermediate palladium(II) methyl iodide complex. They also 
demonstrated facile $\mathrm{CO}$ insertion into the $\mathrm{Pd}-\mathrm{Me}$ bond giving promise for activity in $53 \mathrm{CO} /$ ethylene copolymerisation catalysis. ${ }^{15}$ Detailed carbonylation kinetic studies were 54 also conducted.

Additionally, presumably owing to limited synthetic strategies available in accessing these complexes, to the best of our knowledge, detailed polymerisation-type catalysis studies featuring this important class of cationic chelated bis(NHC) methylpalladium(II) complexes are conspicuously absent in the literature. Hence, we herein report an alternate synthetic pathway to access a previously reported cationic chelated bis(NHC) methylpalladium(II) complex, along with its utility in $\mathrm{CO} /$ ethylene copolymerisation and preliminary studies in ethylene oligomerisation.

\section{Results and Discussions}

64 Synthesis of $\left[\left\{(\mathrm{MesIm})_{2} \mathrm{CH}_{2}\right\} \mathrm{Pd}(\mathrm{Me})(\mathrm{NCMe})\right]\left[\mathrm{PF}_{6}\right]$

65 Slaughter et al. ${ }^{15}$ first synthesised the cationic chelated bis(NHC) methylpalladium(II) acetonitrile complex $\left[\left\{(\mathrm{MesIm})_{2} \mathrm{CH}_{2}\right\} \mathrm{Pd}(\mathrm{Me})(\mathrm{NCMe})\right]\left[\mathrm{BF}_{4}\right], \quad$ D via Scheme 1 . This involved air- and moisture-sensitive free carbene generation and the isolation of the chelated bis(NHC) methylpalladium iodide complex $\left[\left\{(\mathrm{MesIm})_{2} \mathrm{CH}_{2}\right\} \mathrm{Pd}(\mathrm{Me})(\mathrm{I})\right], \mathbf{C}$, which displayed rapid decomposition at room temperature. Therefore, we sought to explore alternate synthetic routes to obtain $\mathbf{D}$ or an analogue thereof.
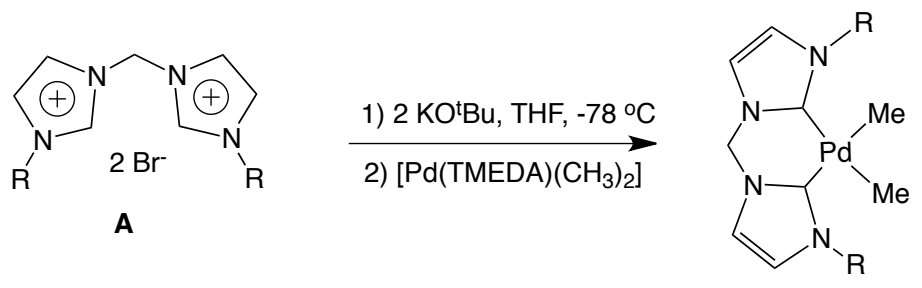

B

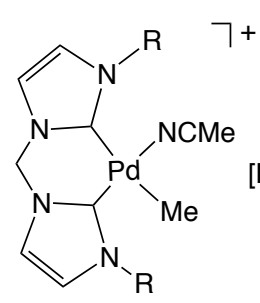

D

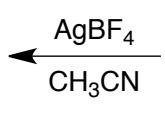<smiles>[R]N1C=CN2CN3C=CN([R])C3[PH](I)(I)C12</smiles>

C

$R=$ 2,4,6-trimethylphenyl

Scheme 1. Literature ${ }^{15}$ reported synthetic route to cationic chelating bis(NHC) palladium methyl acetonitrile complex $\left[\left\{(\mathrm{MesIm})_{2} \mathrm{CH}_{2}\right\} \mathrm{Pd}(\mathrm{Me})(\mathrm{NCMe})\right]\left[\mathrm{BF}_{4}\right], \mathbf{D}$.

Initial attempts were aimed at starting from a pre-formed chelated bis(NHC) palladium dihalide complex $\left[\left\{(\mathrm{MesIm})_{2} \mathrm{CH}_{2}\right\} \mathrm{PdX}_{2}\right](\mathrm{X}=\mathrm{I}, \mathrm{Br}$ or $\mathrm{Cl})$ which can be easily accessed in good yield via in situ deprotonation of the corresponding diimidazolium dihalide salt with $\mathrm{Pd}(\mathrm{OAc})_{2}{ }^{12}$ Furthermore, treatment with methylating agents to form a complex analogous to $\mathbf{C}$, followed by $\mathrm{Ag}(\mathrm{I})$ salt halide abstraction would in principle afford $\mathbf{D}$. $\mathrm{SnMe}_{4}$ and MeLi were tested as potential methylating agents (Scheme 2). 


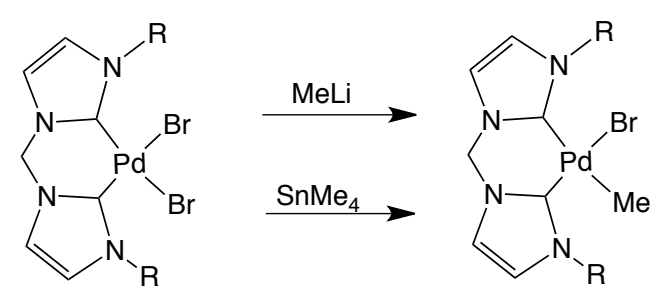

$R=2,4,6$-trimethylphenyl

Scheme 2. Proposed methylation reactions with pre-formed [ $\left.\left\{(\mathrm{MesIm})_{2} \mathrm{CH}_{2}\right\} \mathrm{PdBr}_{2}\right]$ with $\mathrm{SnMe}_{4}$ and MeLi.

Attempted synthesis according to Scheme 2 only resulted in intractable metal complex decomposition mixtures, which may be due to innate instability of the corresponding palladium(II) methyl halide complexes or possible ligand decomposition as noted by the formation of large amounts of palladium black. This led to the use of the more readily accessible [(COD)PdBrMe] (COD = 1,5-cyclooctadiene) complex with the already intact $\mathrm{Pd}-\mathrm{Me}$ bond. The labile COD ligand can be easily replaced with the target bis(NHC) ligand of interest. Synthesis of [(COD)PdBrMe] followed a modified literature procedure involving the methylation of [(COD) $\left.\mathrm{PdBr}_{2}\right]$ with tetramethyltin and was structurally authenticated with single crystal X-ray diffraction analysis (see ESI). Ligand substitution was attempted via $\mathrm{Ag}(\mathrm{I})$ carbene transmetallation. Consistent with literature precedent of NHC silver complexes forming a diverse range of structures and aggregates, ${ }^{16,17}$ initial reactions between $\mathrm{Ag}_{2} \mathrm{O}$ and diimidazolium dihalide salts resulted in inseparable product mixtures from which reaction stoichiometries were difficult to control, as the bis(NHC) disilver complexes had complex $\mathrm{Ag}_{\mathrm{x}} \mathrm{Br}_{\mathrm{y}}$ counteranions that varied with recrystallisation conditions. Recent bis(NHC) palladium catalysed $\mathrm{C}-\mathrm{H}$ activation studies performed by Strassner et al. ${ }^{18}$ also attempted to exploit the $\mathrm{Ag}(\mathrm{I})$ NHC transmetallation route to generate chelating bis(NHC) complexes but only resulted in dinuclear methylpalladium(II) complexes with bridging bis(NHC) ligands despite dilution and substituent modifications. A new approach was pursued by substitution of coordinating bromide counteranions with the non-coordinating $\left[\mathrm{PF}_{6}\right]^{-}$anion.
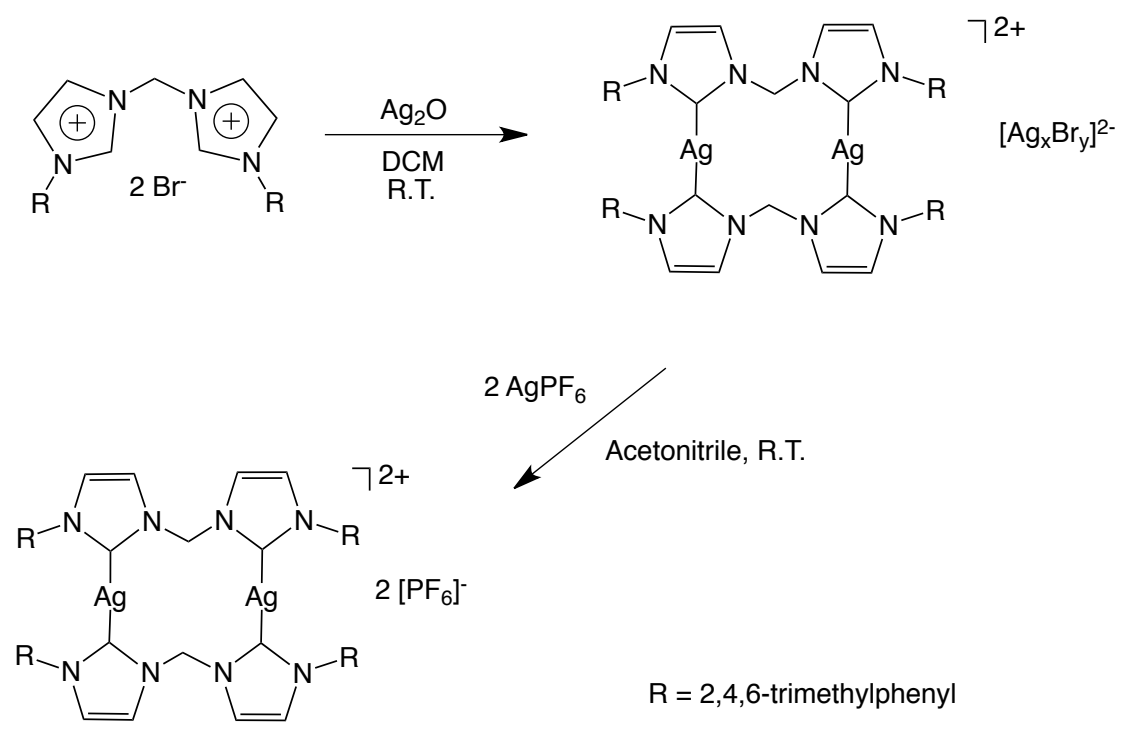

1

104 Scheme 3. Synthesis of 1 via $\mathrm{Ag}_{2} \mathrm{O}$ deprotonation and metallation of diimidazolium salt $\mathbf{A}$ followed by halide abstraction and anion substitution. 
Our new approach involved firstly stirring the diimidazolium dibromide, $\mathbf{A}$ with $\mathrm{Ag}_{2} \mathrm{O}$ in dichloromethane with the exclusion of light for 24 hours, followed by solvent removal under vacuum. The resulting light brown solid was re-dissolved in acetonitrile and 2 equivalents of $\mathrm{AgPF}_{6}$ was added (Scheme 3). This was stirred for 1 hour at room temperature with the exclusion of light, filtered to remove $\mathrm{AgBr}$ salts, and the solvent removed under vacuum to afford a colourless solid, [\{(MesIm $\left.\left.)_{2} \mathrm{CH}_{2}\right\}_{2} \mathrm{Ag}_{2}\right]\left[\mathrm{PF}_{6}\right]_{2} \mathbf{1}$ in $40 \%$ yield. ${ }^{1} \mathrm{H}$ NMR spectroscopic studies supported the formation of the bis(NHC) $\mathrm{Ag}(\mathrm{I})$ complex with the absence of imidazolium NCHN signals. The presence of three methyl signals at $2.44,1.61$ and $1.28 \mathrm{ppm}$ indicated restricted rotation of the mesityl rings in solution at room temperature. Distinct signals at 7.27 and $6.53 \mathrm{ppm}$ supports a twisted boat conformation of the bis(NHC) silver macrocyclic ring, resulting in an $A B$ spin system of the methylene $\mathrm{CH}_{2}$ hydrogen atoms. Single crystals were grown by vapour diffusion of diethyl ether into a saturated acetonitrile solution. X-ray crystal structure analysis was consistent with the NMR spectroscopic data discussed above, and the structure of $\mathbf{1}$ (Figure 1 ) is analogous to the previously reported $\left[\mathrm{BF}_{4}\right]^{-}$analogue. ${ }^{17}$ $\mathrm{Ag}-\mathrm{C}$ (carbene) bond lengths were comparable at 2.072(6) - 2.084(6) $\AA$ with a weak $\mathrm{Ag}-\mathrm{Ag}$ interaction at 3.111(9) $\AA$.

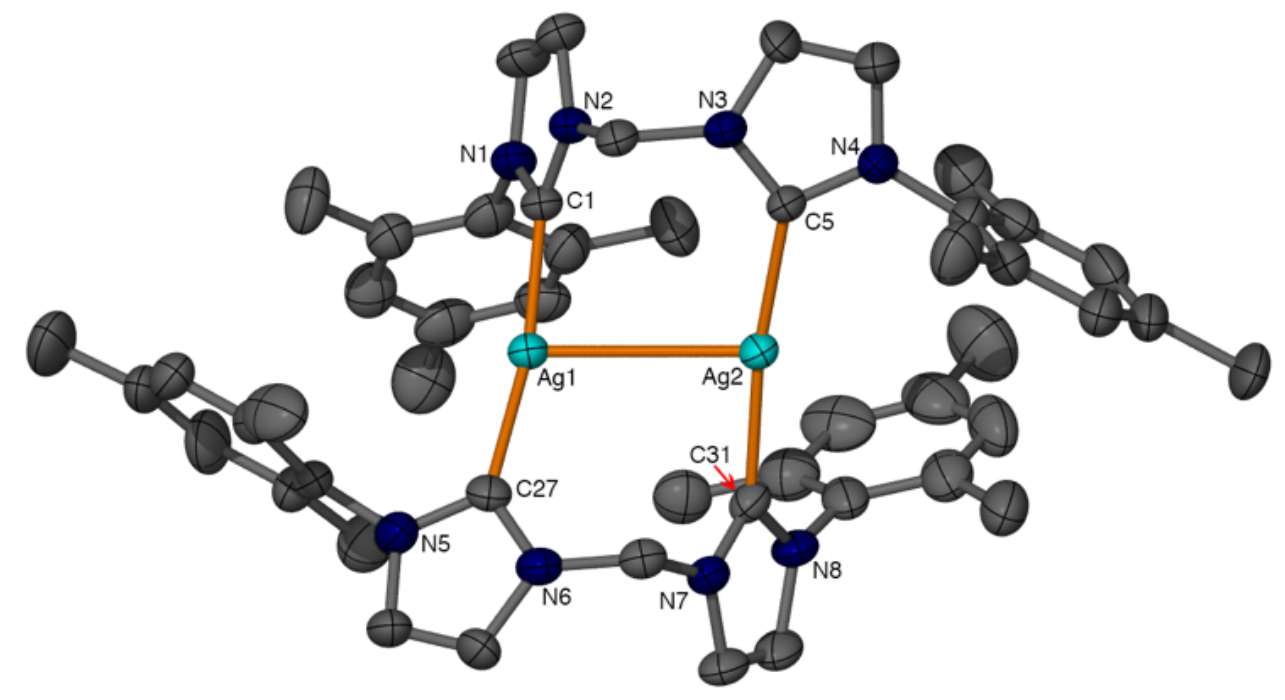

Figure 1. Crystal structure of dicationic bridging bis(NHC) Ag(I) complex $\left[\left\{(\mathrm{MesIm})_{2} \mathrm{CH}_{2}\right\}_{2} \mathrm{Ag}_{2}\right]\left[\mathrm{PF}_{6}\right]_{2}$ 1. Thermal ellipsoids are shown at the $50 \%$ probability level. All hydrogen atoms and $\left[\mathrm{PF}_{6}\right]^{-}$anions are removed for clarity. Selected bond lengths $(\AA)$ and angles $\left({ }^{\circ}\right)$ : Ag1 $\cdots \mathrm{Ag} 2$ 3.1113(9), Ag1-C1,C27 2.084(6), 2.081(6), Ag2C5,C31 2.072(6), 2.074(6), C1-Ag1-C27 172.6(2), C5-Ag2-C31 170.4(2), Ag1-C1$\mathrm{N} 1, \mathrm{~N} 2$ 128.4(5), 127.5(5), Ag1-C27-N5,N6 122.5(4), 133.4(5), Ag2-C5-N3,N4 133.7(5), 122.8(4), Ag2-C31-N7,N8 127.2(5), 128.2(5).

Synthesis of the target cationic palladium(II) methyl acetonitrile adduct ( $\mathrm{PF}_{6}{ }^{-}$analogue of D) proceeded in one-step without the need for dry solvents or an inert atmosphere, also circumventing the previously reported unstable intermediate C. ${ }^{15}$ Transmetallation reactions of 1 with 2 equivalents of [(COD)PdBrMe] were conducted in acetonitrile with the exclusion of light for 1 hour at room temperature, affording an off-white solution with grey $\mathrm{AgBr}$ precipitate (Scheme 4). This was removed via filtration and the solvent removed in vacuo, affording an off-white solid. Purification by recrystallisation produced colourless rods of $\left[\left\{(\mathrm{MesIm})_{2} \mathrm{CH}_{2}\right\} \mathrm{Pd}(\mathrm{Me})(\mathrm{NCMe})\right]\left[\mathrm{PF}_{6}\right] 2$ in $80 \%$ yield, suitable for $\mathrm{X}$-ray crystal structure determination. ${ }^{1} \mathrm{H}$ NMR spectroscopic analysis 
showed NHC ligand resonances similar to that reported for Slaughter's analogous $\left[\mathrm{BF}_{4}\right]^{-}$ complex. ${ }^{15}$ Characteristic resonances at -0.56 and $1.86 \mathrm{ppm}$ were indicative of $\mathrm{Pd}-\mathrm{CH}_{3}$ and $\mathrm{Pd}-\mathrm{NCCH}_{3}$ hydrogen atoms, respectively, and the absence of COD resonances supported successful ligand substitution. Elemental composition was also confirmed via satisfactory microanalysis. X-ray crystallographic studies revealed the bonding connectivity of the bis(NHC) ligands to be chelated in a mononuclear palladium complex (Figure 2). $\mathrm{Pd}-\mathrm{C}$ (carbene, trans to acetonitrile), $\mathrm{Pd}-\mathrm{C}$ (carbene, trans to methyl), $\mathrm{Pd}-\mathrm{N}$ (acetonitrile) and $\mathrm{Pd}-\mathrm{C}$ (methyl) bond lengths were as expected at $1.986(5), 2.092(5), 2.056(5)$ and 2.072(6) $\AA$, respectively, as was the bis(NHC) chelate bite angle at $86.02(2){ }^{\circ}$. The longer $\mathrm{Pd}-\mathrm{C}$ (carbene) bond trans to the $\mathrm{CH}_{3}$ ligand is consistent with the fact that $\mathrm{CH}_{3}$ is a strong $\sigma$-donor. Such trans influence of a $\mathrm{CH}_{3}$ ligand is also seen in other cationic palladium methyl complexes. ${ }^{15}$

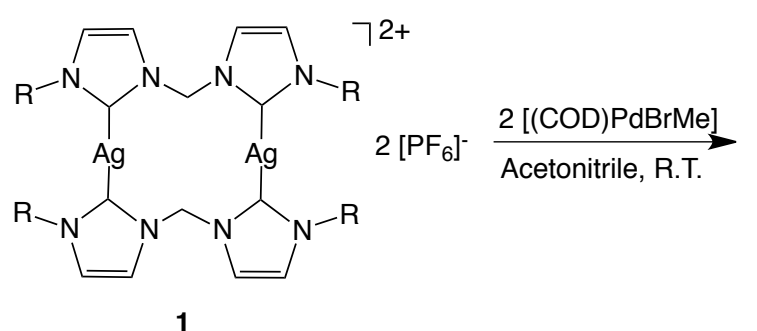

$\mathrm{R}=2,4,6$-trimethylphenyl

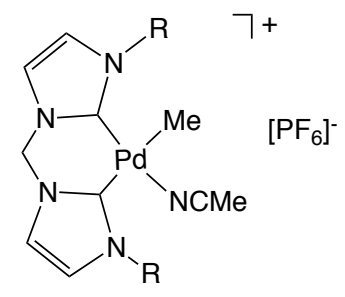

2

Scheme 4. Synthesis of $\left[\left\{(\mathrm{MesIm})_{2} \mathrm{CH}_{2}\right\} \mathrm{Pd}(\mathrm{Me})(\mathrm{NCMe})\right]\left[\mathrm{PF}_{6}\right], 2$ via air and moisture tolerant transmetallation reaction of 1 with (COD)PdBrMe.

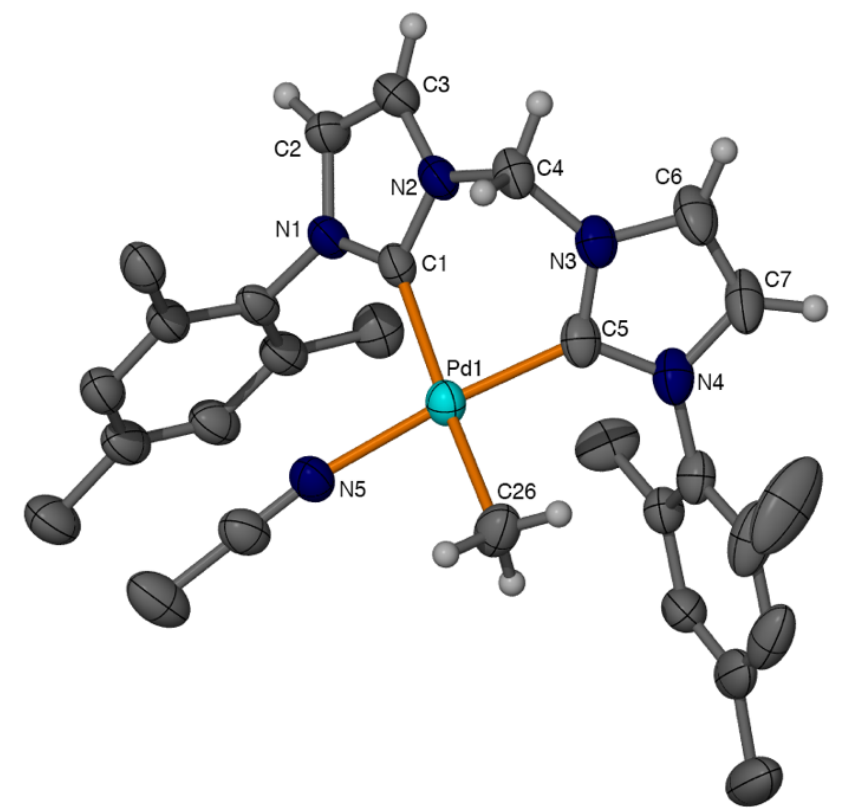

Figure 2. Crystal structure of cationic chelated bis(NHC) palladium methyl acetonitrile complex $\left[\left\{(\mathrm{MesIm})_{2} \mathrm{CH}_{2}\right\} \mathrm{Pd}(\mathrm{Me})(\mathrm{NCMe})\right]\left[\mathrm{PF}_{6}\right], 2$. Thermal ellipsoids are shown at the $50 \%$ probability level. All hydrogen atoms and $\left[\mathrm{PF}_{6}\right]^{-}$anions are removed for clarity. Selected bond lengths $(\AA)$ and angles $\left(^{\circ}\right)$ : Pd1-C1,C5 2.092(5), 1.986(5), Pd1-N5 2.056(5), Pd1-C26 2.072(6). C5-Pd1-C1 86.02(2), N5-Pd1-C26 85.29(2), C1-Pd1N5,C26 97.92(19), 173.30(2), C5-Pd1-C26,N5 91.12(3), 173.30(2), Pd1-C1-N1,N2 
Kinetic experiments performed by Slaughter showed facile $\mathrm{CO}$ insertion into the $\mathrm{Pd}-\mathrm{CH}_{3}$ bond of $\mathbf{D}$ resulting in an equilibrium between a Pd-acyl complex and a Pd-CO methyl complex, of which the Pd-CO complex was structurally characterised. ${ }^{15}$ However, to the best of our knowledge, subsequent reactions of this cationic chelated bis(NHC) methylpalladium(II) complex and its acyl derivative with ethylene remain absent in the literature. Our initial investigations focussed on the catalytic performance of $\mathbf{2}$ in the copolymerisation of carbon monoxide and ethylene given the established reactivity of 2 with $\mathrm{CO}$. A summary of the catalytic trials is given in Table 1 .

Table 1. CO/ethylene copolymerisation catalysed by $\mathbf{2}^{\mathrm{a}}$.

\begin{tabular}{cccccc}
\hline Entry & Complex & Solvent & $\begin{array}{c}\text { Temperature } \\
\left({ }^{\circ} \mathbf{C}\right)\end{array}$ & $\begin{array}{c}\text { Time } \\
(\mathbf{h})\end{array}$ & $\begin{array}{c}\text { Copolymer Yield } \\
(\mathbf{g} \text { copolymer/ mmol Pd) }\end{array}$ \\
\hline 1 & 2 & $\mathrm{MeOH}$ & $\mathrm{R} . \mathrm{T}$. & 2 & 0.418 \\
2 & 2 & $\mathrm{MeOH}$ & 70 & 2 & 1.37 \\
$3^{\mathrm{b}}$ & 2 & $\mathrm{MeOH}$ & 70 & 2 & 2.70 \\
4 & 2 & $\mathrm{CH}_{2} \mathrm{Cl}_{2}$ & 70 & 2 & 7.70 \\
5 & 2 & $\mathrm{CH}_{2} \mathrm{Cl}_{2}$ & 70 & 24 & 8.43 \\
\hline
\end{tabular}

${ }^{a}$ Conditions: 20 bar CO, 20 bar $\mathrm{CH}_{2} \mathrm{CH}_{2}, 2.89 \times 10^{-2} \mathrm{mmol} 2$, volume $=50 \mathrm{~mL}$. b Temperature of the reaction was slowly increased from $50{ }^{\circ} \mathrm{C}$ to $70^{\circ} \mathrm{C}$ over the course of $1 \mathrm{hr}$ and maintained at $70{ }^{\circ} \mathrm{C}$ for the remaining catalysis experiment.

All copolymerisation trials resulted in low copolymer yields. However, in comparison with previous reports featuring dicationic bis(NHC) palladium(II) complexes, ${ }^{19}$ in our hands complex 2 remains more active. Reaction solutions were also analysed by GC-MS and no evidence for short chain CO/ethylene co-oligomers was found consistent with previous studies. ${ }^{19}$ Increasing the temperature from room temperature to $70{ }^{\circ} \mathrm{C}$ improved catalyst performance $c a$. threefold. As seen in Table 1, the reaction solvent also seemed to play an important role in catalyst activity as reflected by copolymer yields. Reactions performed in $\mathrm{MeOH}$ resulted in comparatively less copolymer than those conducted in $\mathrm{CH}_{2} \mathrm{Cl}_{2}$. The role of $\mathrm{MeOH}$ as a possible contributor to the transformation of $\mathbf{2}$ into a catalytically inactive complex is presumably linked to previous theoretical ${ }^{20}$ and experimental ${ }^{21,22}$ reports on $\sigma$-bond metathesis reactions involving alcohols and $\mathrm{Pd}-\mathrm{Me}$ complexes. $\mathrm{MeOH}$ coordination followed by elimination of methane would result in the formation of a $\mathrm{Pd}-\mathrm{OMe}$ species that can undergo $\beta$ hydrogen elimination generating a $\mathrm{Pd}-\mathrm{H}$ complex. Although, in theory, this would be another initiation pathway for $\mathrm{CO} /$ ethylene copolymerisation, however, our previous reports $^{23}$ have suggested that bis(NHC) $\mathrm{Pd}(\mathrm{II})-\mathrm{H}$ complexes are likely to undergo reduction to $\mathrm{Pd}(\mathrm{I})$ species that are yet to show activity in this class of catalysis.

Methanol solvent non-innocence warranted the need for a change in catalysis solvent, in this case from $\mathrm{MeOH}$ to $\mathrm{CH}_{2} \mathrm{Cl}_{2}$. Employing $\mathrm{CH}_{2} \mathrm{Cl}_{2}$ nearly tripled the copolymer yield presumably due to extended catalyst life. However, copolymer yield did not increase greatly with increased reaction time (entry 5), suggesting that long-term catalyst stability is still an issue with this system. This may be due to instability of the intermediate catalytic species resulting from chain termination processes, which could also generate a $\mathrm{Pd}-\mathrm{H}$ species. Furthermore, in the absence of monomer substrates, 2 does decompose both in solution and solid state at room temperature over a period of 6 hours in solution and 2 days in solid state affording palladium black, likely via $\mathrm{Pd}-\mathrm{CH}_{3}$ reductive elimination as is commonly seen for NHC Pd-alkyl complexes. ${ }^{6}$

Slaughter and co-workers performed kinetic investigations of carbonylation reactions relevant to $\mathrm{CO} /$ ethylene copolymerisation and were able to structurally authenticate a cationic methylpalladium $\mathrm{CO}$ species. In situ detection of a $\mathrm{Pd}$-acyl species resulting from $\mathrm{CO}$ insertion into the $\mathrm{Pd}-\mathrm{CH}_{3}$ bond was also achieved. ${ }^{15}$ However, to the best of our knowledge, what remains absent is the investigation of ethylene insertion into the $\mathrm{Pd}-\mathrm{CH}_{3}$ or $\mathrm{Pd}-\mathrm{acyl}$ bond for this class of chelating bis(NHC) ligands. 
${ }^{1} \mathrm{H}$ NMR spectroscopic studies investigating ethylene insertion processes were conducted in $\mathrm{CD}_{2} \mathrm{Cl}_{2}$ under 1 atmosphere of ethylene at room temperature. A sharp singlet at $5.36 \mathrm{ppm}$ confirmed the presence of ethylene in solution; the sample was not replenished with ethylene after initial charging (Figure 3). Ethylene insertion into the $\mathrm{Pd}-\mathrm{Me}$ bond proved to be quite rapid, as introduction of ethylene immediately resulted in a reduction of signal intensity for the $\mathrm{Pd}-\mathrm{CH}_{3}$ hydrogen atoms at $-0.53 \mathrm{ppm}$ and formation of oligomeric products of ethylene with multiplets at $c a .1 .63,1.65,4.85,5.15$ and $5.90 \mathrm{ppm}$.

$$
\text { Complex } 2 \text { upon immediate addition of } \mathrm{C}_{2} \mathrm{H}_{4} \text { in } \mathrm{CD}_{2} \mathrm{Cl}_{2}
$$

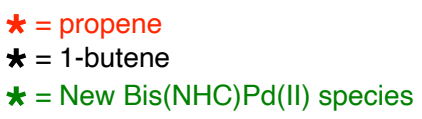

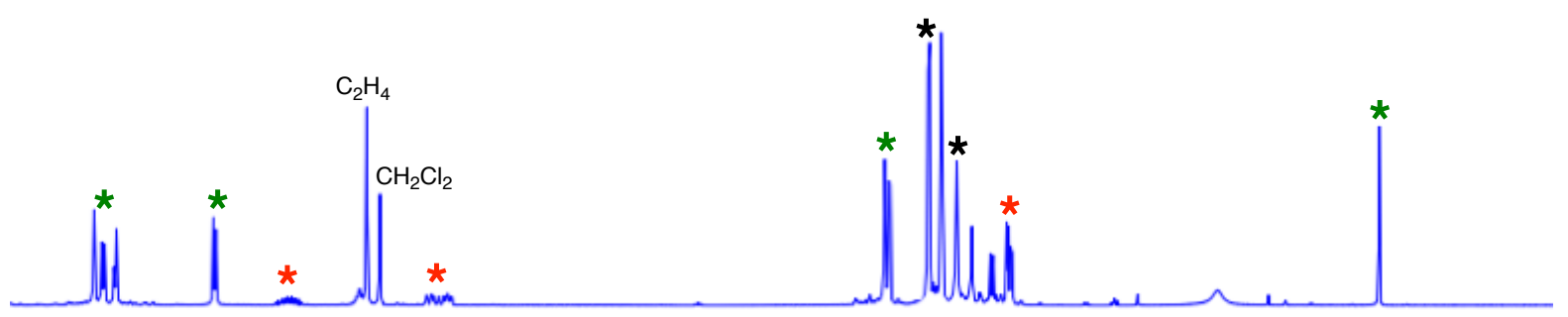

Complex 2 in $\mathrm{CD}_{2} \mathrm{Cl}_{2}$

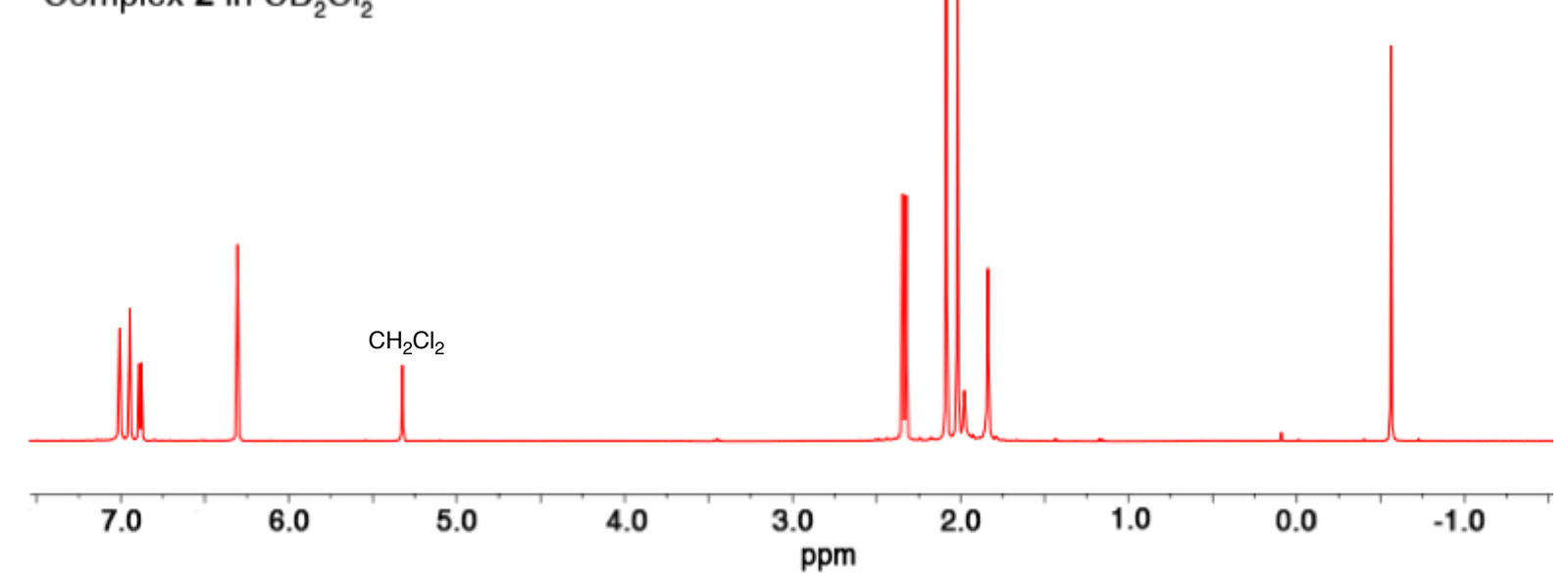

Figure 3. Room temperature ${ }^{1} \mathrm{H}$ NMR spectra of complex 2 in $\mathrm{CD}_{2} \mathrm{Cl}_{2}$ and upon immediate addition of 1 atmosphere of $\mathrm{C}_{2} \mathrm{H}_{4}$.

Concomitant with the consumption of ethylene was the formation of Pd black and also what is likely to be ligand decomposition as seen in the subsequent complexity of the ${ }^{1} \mathrm{H}$ NMR spectrum. In order to better identify the ethylene oligomer products seen in the ${ }^{1} \mathrm{H}$ NMR spectrum, 2 was placed in a high-pressure (10 bar) Young's NMR tube and charged with 10 bar of ethylene. The sample was kept at $0{ }^{\circ} \mathrm{C}$ for 24 hours after which saw complete consumption of ethylene and catalyst decomposition as indicated by the formation of Pd black and absence of coordinated ligand resonances in the NMR spectrum.

The formation of propene is suggested by multiplets at 5.95 and $1.66 \mathrm{ppm}$, indicating propene $\mathrm{CH}$ and $\mathrm{CH}_{3}$ protons respectively, along with $\mathrm{CH}_{2}$ hydrogen resonances at 4.97 and $5.04 \mathrm{ppm}$. 1-butene was also indicated by $\mathrm{CH}_{2}$ and $\mathrm{CH}_{3}$ signals at 2.11 and 1.90 $\mathrm{ppm}$, respectively, along with other signals indicative of unsaturated oligomeric products. Analysis by GC-MS confirmed the formation of propene, 1-butene, cis- and trans-2-butene, along with small amounts of $\mathrm{C}_{6}$ alkenes from ethylene trimerisation or ethylene/butene codimerisation. 2 showed a total TON of 120 with $c a$. a 9:1 $\mathrm{C}_{4} / \mathrm{C}_{6}$ ethylene oligomer product ratio. The proposed mechanism of ethylene dimerisation catalysed by 2 is shown in Scheme 5, and is analogous to that established previously. ${ }^{24,25}$ 
Propene results from initial insertion into the Pd-methyl bond (chain initiation), the butenes are subsequently formed catalytically by ethylene insertion reactions into a $\mathrm{Pd}-$ $\mathrm{H}$ species followed by $\beta$-hydrogen elimination.

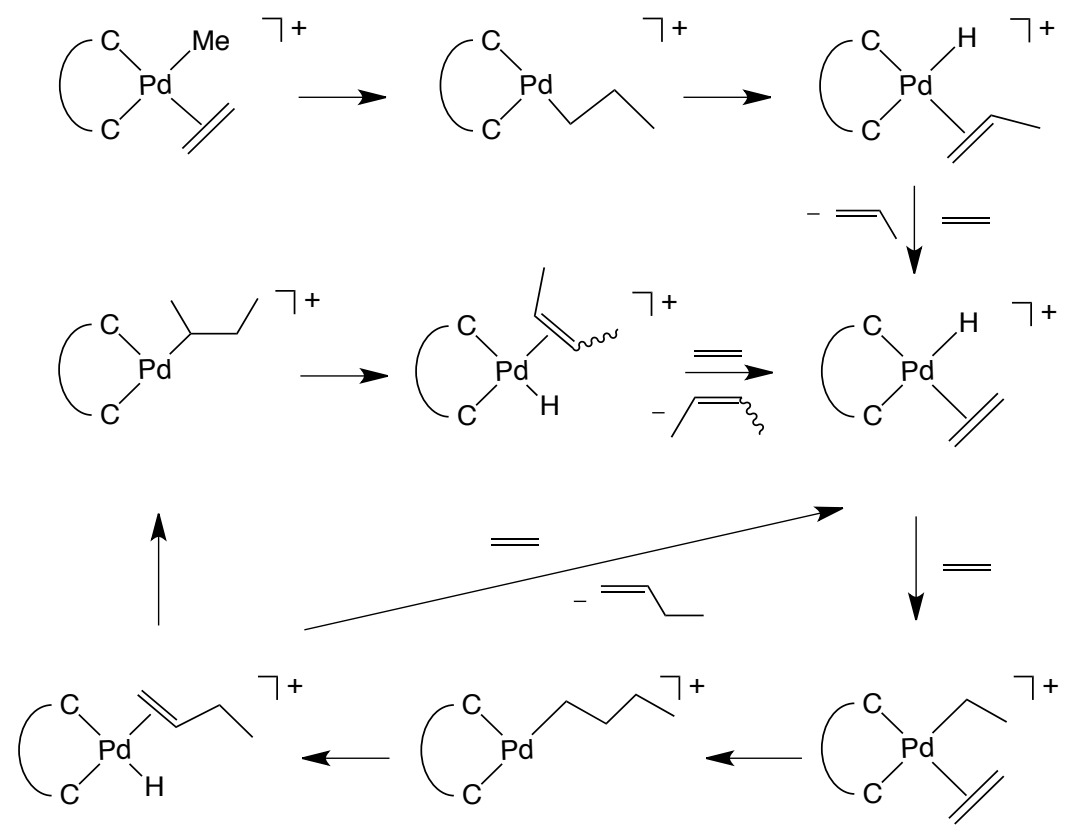

Scheme 5. Proposed reaction mechanism showing the formation of ethylene oligomers.

In both atmospheric and high-pressure experiments, upon introduction of ethylene to a $\mathrm{CD}_{2} \mathrm{Cl}_{2}$ solution of 2 , a number of other spectroscopic changes can be seen which are indicative of structural transformations occurring at the Pd centre. Concomitant with a decrease in the $\mathrm{Pd}-\mathrm{CH}_{3}$ signal intensity at $-0.53 \mathrm{ppm}$ is the appearance of a broad singlet at $0.42 \mathrm{ppm}$. This signal disappeared when all ethylene was consumed, suggesting it to possibly be associated with a transient $\mathrm{Pd}$-alkyl complex(es) undergoing rapid $\beta-\mathrm{H}$ elimination and insertion processes. Another characteristic change in the NMR spectrum can be seen at $6.34 \mathrm{ppm}$, which corresponds to the $\mathrm{CH}_{2}$ methylene bridge hydrogen atoms of the ligand. Upon reaction with ethylene an adjacent singlet at 6.33 ppm appears which increases in size with time until the singlet at $6.34 \mathrm{ppm}$ disappears. This suggests the complete transformation of $\mathbf{2}$ into a secondary species. Attempted isolation of olefin insertion $\mathrm{Pd}$ complexes proved difficult, nor could $\mathrm{Pd}-\mathrm{H}$ resonances be observed in low temperature ${ }^{1} \mathrm{H}$ NMR spectroscopic experiments which may have resulted from $\mathrm{Pd}$-alkyl complexes bearing $\beta$-hydrogens prone to reductive decomposition processes, and hence was not further pursued.

\section{Conclusion}

In conclusion, an improved synthetic route for the preparation of cationic chelated bis(NHC) palladium(II) methyl complexes has been developed via a Ag(I) carbene transmetallation process with [(COD)PdBrMe]. This method proved to be high yielding and tolerant to both air and moisture affording pure complex 2 avoiding the putative unstable and prone to decomposition intermediate chelated bis(NHC) PdXMe complex and access to highly sensitive free carbene species which may have played a role in the lack of detailed studies present in the literature featuring complexes analogous to 2 . Although not presented in this work, our newly developed method has the potential to be applied to a wider range of bis(NHC) ligands and late transition metal centres relevant to homogeneous polymerisation catalysis.

Preliminary $\mathrm{CO} /$ ethylene copolymerisation and ethylene homooligomerisation studies were also conducted in methanol and $\mathrm{CH}_{2} \mathrm{Cl}_{2}$. Copolymer yields seemed to be solvent dependent with catalysis conducted in $\mathrm{CH}_{2} \mathrm{Cl}_{2}$ affording the highest yields in 
this study. Reactions in methanol produced considerably lower copolymer yields suggestive of some degree of solvent interaction with the active catalytic species.

Complex 2 was also shown to be active in ethylene homooligerisation producing 1-, 2-, cis- and trans-butenes, along with traces of $\mathrm{C}_{6}$ alkenes rationalised by literature reported reaction mechanisms. However, catalyst performance in both copolymerisation and homooligomerisation over a range of conditions proved poor, catalyst complex stability remains an obstacle for this system.

Further work regarding reaction mechanisms of methanol solvent non-innocence with regards to catalyst $\mathbf{2}$ is topical for this class of chelated bis(NHC) palladium(II) complexes. Understanding bis(NHC) ligand lability and solvent-dependent complex reactivity is paramount towards revealing catalyst stability and developing improved catalyst design.

289

290

291

292

293

294

295

296

297

298

299

300

301

302

303

304

305

306

307

308

309

310

311

312

313

314

315

316

317

318

319

320

321

322

323

324

325

326

327

328

\section{Experimental}

\section{General Considerations}

All syntheses of imidazolium salts and anion exchange reactions of metal complexes were carried out in air. Some analyses were performed in a dry glove box (Innovative Technologies) under a nitrogen atmosphere. Anhydrous dimethylsulfoxide and methanol were purchased from Sigma-Aldrich and stored over $3 \AA$ molecular sieves. CP grade ethylene (BOC gases) were purified by passage through a column of activated $3 \AA$ molecular sieves and alumina, and CP grade carbon monoxide (BOC gases) was used as received. 1,1'-dimesityl-3,3'-methylenediimidazolium dibromide, ${ }^{12}$ [(COD)PdBrMe ${ }^{26}$ and $\left[\left\{(\mathrm{MesIm})_{2} \mathrm{CH}_{2}\right\} \mathrm{PdBr}_{2}\right]^{12}$ were prepared according to literature methods. All other reagents were purchased from Sigma-Aldrich and used as received. NMR spectra were recorded on a Varian Mercury Plus 300 spectrometer $\left({ }^{1} \mathrm{H}, 299.9 \mathrm{MHz} ;{ }^{13} \mathrm{C}\left\{{ }^{1} \mathrm{H}\right\}, 75.4\right.$ $\mathrm{MHz}$ ) in $\mathrm{CDCl}_{3}$ or DMSO- $d_{6}$ at $20{ }^{\circ} \mathrm{C}$ unless otherwise noted. ${ }^{1} \mathrm{H}$ NMR and ${ }^{13} \mathrm{C} \mathrm{NMR}$ spectra were referenced to the residual ${ }^{1} \mathrm{H}$ resonance of the solvent residual peaks, while ${ }^{13} \mathrm{C}$ NMR spectra were referenced to the deuterated ${ }^{13} \mathrm{C}$ resonance. $J$ values are given in Hz. Elemental analyses were carried by the Central Science Laboratory at the University of Tasmania using a Carlo Erba EA1108 Elemental Analyser or Medac Ltd, UK. GC-MS analyses were carried by the Central Science Laboratory at the University of Tasmania using a Varian 3800 GC coupled to a Varian 1200 triple quadrupole MS. Electronic Supplementary Information (ESI) available: CCDC references numbers 1863141, 1863142 and 186143

\section{Syntheses}

[\{(MesIm) $\left.\left.)_{2} \mathbf{C H}_{2}\right\}_{2} \mathbf{A g}_{2}\right]\left[\mathbf{P F}_{6}\right]_{2}$ - (1) $\mathrm{Ag}_{2} \mathrm{O}(0.67 \mathrm{~g}, 1.36 \mathrm{mmol})$ and 1, 1'-dimesityl-3,3'methylenediimidazolium dibromide $(0.32 \mathrm{~g}, 1.22 \mathrm{mmol})$ were stirred in $25 \mathrm{~mL} \mathrm{CH}_{2} \mathrm{Cl}_{2}$ in exclusion of light at room temperature overnight. The mixture had all solvent removed in vacuo affording a grey solid that was redissolved in $25 \mathrm{~mL} \mathrm{CH}_{3} \mathrm{CN}$ and stirred with $\mathrm{AgPF}_{6}(0.68 \mathrm{~g}, 2.70 \mathrm{mmol})$ for 2 hours at room temperature. This resulted in a clear solution with a grey precipitate that was removed via Celite filtration and all solvent removed in vacuo. The off-white solid was recrystallised via layering of $\mathrm{Et}_{2} \mathrm{O}$ over a saturated $\mathrm{CH}_{3} \mathrm{CN}$ solution affording colourless crystals of $1(0.63 \mathrm{~g}, 0.49 \mathrm{mmol}$, 40\%). ${ }^{1} \mathrm{H}$ NMR (DMSO-d $): \delta 8.08(\mathrm{~s}, 4 \mathrm{H}, H \mathrm{C}=\mathrm{CH}), 7.49(\mathrm{~s}, 4 \mathrm{H}, H \mathrm{C}=\mathrm{CH}), 7.27(\mathrm{~d}$, $\left.2 \mathrm{H}, J=13.6 \mathrm{~Hz}, \mathrm{NCH}_{2} \mathrm{~N}\right), 7.09(\mathrm{~s}, 4 \mathrm{H}, \operatorname{aryl}-H), 6.97(\mathrm{~s}, 4 \mathrm{H}, \operatorname{aryl}-H), 6.53(\mathrm{~d}, 2 \mathrm{H}, J=$ $\left.13.6 \mathrm{~Hz}, \mathrm{NCH}_{2} \mathrm{~N}\right), 2.44(\mathrm{~s}, 12 \mathrm{H}, p$ - or $m$-aryl-CH$), 1.61\left(\mathrm{~s}, 12 \mathrm{H}, p\right.$ - or $m$-aryl-C $\left.\mathrm{CH}_{3}\right)$, $1.28(\mathrm{~s}, 12 \mathrm{H}, p$ - or $m$-aryl-CH$) .{ }^{13} \mathrm{C}$ NMR (DMSO-d $): \delta 182.4$ (carbene-C), 180.5 (carbene-C), 139.2 (aryl-C), 135.4 (aryl-C), 129.6 (aryl-C), 125.1 (aryl-C), 122.8 (arylC), $65.4\left(\mathrm{NCH}_{2} \mathrm{~N}\right), 64.0\left(\mathrm{NCH}_{2} \mathrm{~N}\right), 21.2\left(\mathrm{CH}_{3}\right), 17.2\left(\mathrm{CH}_{3}\right), 16.9\left(\mathrm{CH}_{3}\right)$. Found: $\mathrm{C}, 46.87$; $\mathrm{N}, 8.48 ; \mathrm{H}, 4.85$. Calc. for $\mathrm{C}_{50} \mathrm{H}_{56} \mathrm{~N}_{8} \mathrm{Ag}_{2} \mathrm{P}_{2} \mathrm{~F}_{12}: \mathrm{C}, 47.11 ; \mathrm{N}, 8.79 ; \mathrm{H}, 4.43$. 


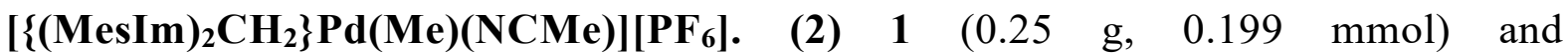

[(COD)PdBrMe] $(0.12 \mathrm{~g}, 0.399 \mathrm{mmol})$ were dissolved and stirred in $25 \mathrm{~mL} \mathrm{CH} 3 \mathrm{CN}$ at room temperature with the exclusion of light for 1 hour affording a colourless solution with grey precipitate. This was filtered through Celite and the filtrate had all solvent removed in vacuo. The resulting white solid was re-crystallised via vapour diffusion of $\mathrm{Et}_{2} \mathrm{O}$ into a saturated $\mathrm{CH}_{2} \mathrm{Cl}_{2}$ solution affording colourless rods of $2(0.21 \mathrm{~g}, 0.196$ mmol, 80\%). mp. $230.1{ }^{\circ} \mathrm{C}(\mathrm{dec}) .{ }^{1} \mathrm{H}$ NMR $\left(\mathrm{CD}_{2} \mathrm{Cl}_{2}\right): \delta 7.60(\mathrm{dd}, 2 \mathrm{H}, J=4.8 \mathrm{~Hz}, 1.5$ $\mathrm{Hz}, H \mathrm{C}=\mathrm{CH}), 7.02(\mathrm{~s}, 2 \mathrm{H}, \operatorname{aryl}-H), 6.95(\mathrm{~s}, 2 \mathrm{H}, \operatorname{aryl}-H), 6.89\left(\mathrm{dd}, 2 \mathrm{H},{ }^{3} J_{\mathrm{HH}}=4.5 \mathrm{~Hz}, 1.8\right.$ $\mathrm{Hz}, H \mathrm{C}=\mathrm{CH}), 6.31\left(\mathrm{~s}, 2 \mathrm{H}, \mathrm{NCH}_{2} \mathrm{~N}\right), 2.35(\mathrm{~s}, 3 \mathrm{H}, p$-aryl-CH$), 2.33\left(\mathrm{~s}, 3 \mathrm{H}\right.$, p-aryl-CH $\left.\mathrm{CH}_{3}\right)$, $2.09\left(\mathrm{~s}, 6 \mathrm{H}, o-a r y l-\mathrm{CH}_{3}\right), 2.03\left(\mathrm{~s}, 6 \mathrm{H}, o-\operatorname{aryl}-\mathrm{CH}_{3}\right), 1.85\left(\mathrm{~s}, 3 \mathrm{H}, \mathrm{CH}_{3} \mathrm{CN}\right),-0.56(\mathrm{~s}, 3 \mathrm{H}$, Pd-C $\left.\mathrm{CH}_{3}\right) .{ }^{13} \mathrm{C}$ NMR (DMSO-d $): \delta 182.5$ (carbene-C), 165.7 (carbene-C), 138.8 (aryl$C), 138.7$ (aryl-C), 136.1 (aryl-C), 135.9 (aryl-C), 135.3 (aryl-C), 134.8 (aryl-C), 129.1 $\left(\right.$ aryl-C), 124.5 (aryl-C), 123.5 (aryl-C), $122.4(\operatorname{aryl}-C), 121.6\left(\mathrm{NCCH}_{3}\right), 65.4\left(\mathrm{CH}_{2}\right)$, $21.0\left(\mathrm{CH}_{3}\right), 20.9\left(\mathrm{CH}_{3}\right), 18.7\left(\mathrm{CH}_{3}\right), 18.3\left(\mathrm{CH}_{3}\right), 1.6\left(\mathrm{NCCH}_{3}\right),-8.2\left(\mathrm{Pd}-\mathrm{CH}_{3}\right)$. Found: $\mathrm{C}, 46.83 ; \mathrm{N}, 9.34 ; \mathrm{H}, 4.90$. Calc. for $\mathrm{C}_{28} \mathrm{H}_{34} \mathrm{~N}_{5} \mathrm{PdPF}_{6} \cdot 0.5 \mathrm{CH}_{2} \mathrm{Cl}_{2}: \mathrm{C}, 46.61 ; \mathrm{N}, 9.54 ; \mathrm{H}$, 4.80.

\section{Ethylene/carbon monoxide copolymerisation trials}

$\left[\left\{(\mathrm{MesIm})_{2} \mathrm{CH}_{2}\right\} \mathrm{Pd}(\mathrm{Me})(\mathrm{NCMe})\right]\left[\mathrm{PF}_{6}\right] .2(0.020 \mathrm{~g}, 0.028 \mathrm{mmol})$ was dissolved in methanol or $\mathrm{CH}_{2} \mathrm{Cl}_{2}(40 \mathrm{~mL})$ under argon atmosphere and transferred to a $0.3 \mathrm{~L}$ stainless steel Parr 5500 Compact Mini Reactor also under an argon atmosphere. The autoclave was charged in turn with 20 bar of ethene and 20 bar of carbon monoxide, and stirred for two hours at the appropriate temperature. The autoclave was then chilled with ice before venting to ensure no loss of volatile (co)oligomeric products. The reaction mixture contained a grey solid which was collected via filtration. The reaction solutions were analysed by GS-MS for oligomeric product.

\section{X-Ray Crystallography}

Data for 2 was collected at $-173{ }^{\circ} \mathrm{C}$ on crystals mounted on a Hampton Scientific cryoloop at the MX1 beamline of the Australian Synchrotron, ${ }^{27}$ while data for 1 were collected at $-173{ }^{\circ} \mathrm{C}$ on crystals mounted on a Hampton Scientific cryoloop on Bruker QUEST. The structures were solved by direct methods with SHELXT-2014, refined using full-matrix least-squares routines against $\mathrm{F}^{2}$ with SHELXT-2014, ${ }^{26}$ and visualised using OLEX2. ${ }^{27}$ All non-hydrogen atoms were refined anisotropically. All hydrogen atoms were placed in calculated positions and refined using a riding model with fixed $\mathrm{C}-\mathrm{H}$ distances of $0.95 \AA\left(s p^{2} \mathrm{CH}\right), 1.00 \AA\left(s p^{3} \mathrm{CH}\right), 0.99 \AA\left(\mathrm{CH}_{2}\right), 0.98 \AA\left(\mathrm{CH}_{3}\right)$. The thermal parameters of all hydrogen atoms were estimated as $U_{\text {iso }}(\mathrm{H})=1.2 U_{\text {eq }}(\mathrm{C})$ except for $\mathrm{CH}_{3}$ where $U_{\text {iso }}(\mathrm{H})=1.5 U_{\text {eq }}(\mathrm{C})$. Disorder in solvent molecules were modelled using atom splitting in OLEX2. A summary of crystallographic data for [(COD)PdBrMe], $\mathbf{1}$ and $\mathbf{2}$ is given below.

Crystal data for [(COD)PdBrMe]: $\mathrm{C}_{9} \mathrm{H}_{15} \mathrm{BrPd}, M=309.52$, orthorhombic, $a=$ $6.9300(4), b=10.970(6), c=12.770(7) \AA, U=970.8(3) \AA^{3}, T=100 \mathrm{~K}$, space group $\mathrm{P} 212121$ (no 19), $Z=4,22596$ reflections measured, 2154 unique $\left(R_{\mathrm{int}}=0.0433\right), 2144$ $>4 \sigma(F), R=0.0222$ (observed), $R_{w}=0.0569$ (all data). Crystal data for 1: $\mathrm{C}_{50} \mathrm{H}_{56} \mathrm{~N}_{8} \mathrm{Ag}_{2} \mathrm{P}_{2} \mathrm{~F}_{12} \cdot\left(\mathrm{C}_{4} \mathrm{H}_{10} \mathrm{O}\right)\left(\mathrm{CH}_{3} \mathrm{CN}\right), M=1389.88$, triclinic, $a=13.8979(4), b=$ $22.6233(7), c=23.4706(7) \AA, \alpha=62.8440(10), \beta=85.7340(10), \gamma=73.2260(10) \circ, U$ $=6272.4(3) \AA^{3}, T=100 \mathrm{~K}$, space group $P-1$ (no. 2 ), $Z=4,227109$ reflections measured, 26226 unique $\left(R_{\text {int }}=0.0472\right), 21905>4 \sigma(F), R=0.0327$ (observed), $R_{w}=0.0721$ (all data). Crystal data for $2: \mathrm{C}_{28} \mathrm{H}_{34} \mathrm{~N}_{4} \mathrm{PdPF}_{6}, M=691.97$, monoclinic, $a=12.680(3), b=$ $21.929(4), c=12.918(3) \AA, \beta=117.45(3)^{\circ}, U=3187.5(13) \AA^{3}, T=100 \mathrm{~K}$, space group $P 2_{1} / n$ (no. 14), $Z=4,60816$ reflections measured, 8476 unique $\left(R_{\text {int }}=0.0621\right), 6742>$ $4 \sigma(F), R=0.0639$ (observed), $R_{w}=0.1878$ (all data).

382 There are no conflicts to declare. 


\section{Acknowledgements}

We thank the Australian Research Council and the University of Tasmania for financial support. Assoc. Prof. Noel Davies and Dr. Thomas Rodemann of the UTas Central Science Laboratory are thanked for GC-MS and elemental analysis measurements, respectively. Data for the structure of 2 was obtained on the MX1 beamline at the Australian Synchrotron, Victoria, Australia.

\section{References}

1. Organotransition Metal Chemistry From Bonding to Catalysis; J. F. Hartwig, Ed.; University Science Books: Sausalito, CA, 2010; Chapter 22.

2. The Organometallic Chemistry of the Transition Metals; R. H. Crabtree, Ed.; John Wiley \& Sons, Inc.: Hoboken, NJ, 2014; Chapter 12.

3. L. Guo, W. Liu, C. Chen, Mater. Chem. Front. 2017, 1, 2487

4. J. P. Collins; Acc. Chem. Res. 1968, 1, 138.

5. L. K. Johnson, S. Mecking, M. Brookhart, J. Am. Chem. Soc., 1996, 118, 267.

6. D. S. McGuinness, K. J. Cavell, Organometallics 2000, 19, 4918.

7. a) F. C. Rix, M. Brookhart, P. S. White, J. Am. Chem. Soc., 1996, 118, 4746; b) H. Xu, C. T. Hu, X. Wang, T. Diao, Organometallics, 2017, 36, 4099.

8. D. Bézler, O. Daugulis, M. Brookhart, Organometallics 2017, 36, 443.

9. a) R. E. Black, R. F. Jordan, Organometallics 2017, 36, 3415; b) X. Sui, S. Dai, C. Chen, ACS Catal. 2015, 5, 5932.

10. a) D. Bézler, O. Daugulis, M. Brookhart, Organometallics 2017, 36, 2947; b) Z. Guan, W. J. Marshall, Organometallics 2002, 21, 3580; c) L. O. de la Tabla, I. Matas, P. Palma, E. Álvarez, J. Cámpora, Organometallics 2012, 31, 1006.

11. A. W. Waltman, R. H. Grubbs, Organometallics 2004, 23, 3105.

12. a) M. G. Gardiner, W. A. Herrmann, C.-P. Reisinger, J. Schwarz, M. Spiegler, J. Organomet. Chem. 1999, 572, 239. b) F. E. Hahn, M. Foth, J. Organomet. Chem. 1999, $585,241$.

13. a) R. E. Douthwaite, M. L. H. Green, P. J. Silcock, P. T. Gomes, J. Chem. Soc., Dalton Trans., 2002, 1386; c) R. E. Douthwaite, M. L. H. Green, P. J. Silcock, P. T. Gomes, Organometallics, 2001, 20, 2611.

14. M. G. Gardiner, C. C. Ho, Coord. Chem. Rev. 2018, 375, 373.

15. S. S. Subramanium, L. M. Slaughter, Dalton Trans. 2009, 6930.

16. K. M. Lee, H. M. J. Wang, I. J. B. Lin, Dalton Trans. 2002, 2852.

17. Y. A. Wanniarachchi, M. A. Khan, L. M. Slaughter, Organometallics 2004, 23, 5881.

18. D. Meyer, T. Strassner, J. Organomet. Chem. 2015, 784, 84.

19. Note: Yields are lower when compared to those reported by Herrmann and co-workers despite replicating reaction conditions, presumably due to differences in gas quality and reactor setup; For $\mathrm{CO} /$ ethylene copolymer yields of related complexes in our hands see: M. G. Gardiner, C. C. Ho, F. M. Mackay, D. S. McGuinness, M. Tucker, Dalton Trans., 2013, 42, 7447.

20. A. Milet, A. Dedieu, G. M. Kapteijn, G. van Koten, Inorg. Chem. 1997, 36, 3223.

21. J. Chatt, B. L. Shaw, J. Chem. Soc. 1962, 5075.

22. G. M. Kapteijn, A. Dervisi, D. M. Grove, H. Kooijman, M. T. Lakin, A. L. Spek, G. van Koten, J. Am. Chem. Soc. 1995, 117, 10939.

23. a) P. D. W. Boyd, A. J. Edwards, M. G. Gardiner, C. C. Ho, M. H. Lemee-Cailleau, D. S. McGuinness, A. Rianpanitra, J. W. Steed, D. N. Stringer, B. F. Yates, Angew. Chem., Int. Ed. Engl. 2010, 49, 6315; b) C. R. Vanston, G. J. Kearley, A. J. Edwards, T. A. Darwish, N. R. de Souza, A. J. Ramirez-Cuesta, M. G. Gardiner, Faraday Discuss., 2015, 177, 99 . 
26. R. E. Rulke, J. M. Ernsting, A. L. Spek, C. J. Elseier, P. W. N. M. Leeuwen. K. Vrieze, Inorg. Chem. 1993, 32, 5769.

27. T. M. McPhillips, S. E. McPhillips, H. J. Chiu, A. E. Cohen, A. M. Deacon, P. J. Ellis, E. Garman, A. Gonzalez, N. K. Sauter, R. P. Phizakerley, S. M. Soltis, P. Kuhn, J. Synchrotron Rad. 2000, 9, 401.

28. G. M. Sheldrick, Acta Cryst. 2015, A71, 3.

29. a) L. J. Barbour, J. Supramol. Chem. 2001, 1, 189; b) O. V. Dolomanov, L. J. Bourhis, R. J. Gildea, J. A. K. Howard, H. Puschmann, J. Appl. Cryst. 2009, 42, 339. 
482

483

484 